\title{
AKTSAR
}

ISSN 2622-5255 (online)

Volume 2 Nomor 2, Desember 2019, Halaman 199-214

ISSN 2622-2345 (cetak)

\section{Pengaruh Kualitas Aparatur Daerah, Sistem Akuntansi Keuangan Daerah, dan Pemanfaatan Teknologi Informasi Terhadap Kualitas Laporan Keuangan Pemerintah Daerah (Studi Empiris Satuan Kerja Perangkat Daerah Kabupaten Sukoharjo)}

\author{
$\underline{\text { Yuwita Ariessa Pravasanti }}$ \\ STIE AAS Surakarta \\ yuwita.ariessa.pravasanti@gmail.com \\ Suhesti Ningsih \\ STIE AAS Surakarta \\ hesti.hegi@gmail.com
}

\section{ABSTRACT}

This study aims to determine the effect of the Quality Government Apparatus, Regional Government Accounting System, Utilization of Information Technology on the Quality of Financial Reporting of the Regional Government. Respondents in this study were 72 employees of the Regional Finance Agency of Sukoharjo Regency. Based on the results of processing primary data (questionnaires) with multiple linear regression analysis methods, $F$ test and t-test has known that variables of the Quality Government Apparatus, Regional Government Accounting System, utilization of information technology simultaneously have a significant effect on the Quality of Financial Reporting in the Regional Government. Partially the Quality Government Apparatus does not have a significant effect on the Quality of Financial Reporting of the Regional Government, but the Regional Government Accounting System and Utilization of Information Technology has a significant effect on the Quality of Financial Reporting in the Regional Government.

Keywords: Quality Government Apparatus; Quality of Financial Reporting of the Regional Government; Utilization of Information Technology; Regional Government Accounting System 


\begin{abstract}
ABSTRAK
Penelitian ini bertujuan untuk mengetahui pengaruh Kualitas Aparatur Pemerintah, Sistem Akuntansi Keuangan Pemerintah Daerah, Pemanfaatan Teknologi Informasi terhadap Kualitas Pelaporan Keuangan Pemerintah Daerah. Responden dalam penelitian ini adalah 72 pegawai Badan Keuangan Daerah Kabupaten Sukoharjo. Berdasarkan hasil pengolahan data primer (angket) dengan metode analisis regresi linier berganda, uji F dan uji-t telah diketahui bahwa variabel Kualitas Aparatur Pemerintah, Sistem Akuntansi Keuangan Pemerintah Daerah, pemanfaatan teknologi informasi secara simultan berpengaruh signifikan terhadap Kualitas Pelaporan Keuangan di Pemerintah Daerah. Secara parsial Aparatur Pemerintah yang Berkualitas tidak memiliki pengaruh yang signifikan terhadap Kualitas Pelaporan Keuangan Pemerintah Daerah, tetapi Sistem Akuntansi Keuangan Pemerintah Daerah dan Pemanfaatan Teknologi Informasi memiliki pengaruh yang signifikan terhadap Kualitas Pelaporan Keuangan di Pemerintah Daerah.
\end{abstract}

Kata kunci: Kualitas Aparatur Daerah; Kualitas Laporan Keuangan Pemerintah Daerah; Pemanfaatan Teknologi Informasi; Sistem Akuntansi Keuangan Daerah

\title{
PENDAHULUAN
}

Organisasi sektor publik merupakan sektor ekonomi yang menyediakan berbagai layanan pemerintah kepada masyarakat. Peran lembaga pemerintah sangatlah penting karena pemerintah adalah suatu lembaga atau badan publik yang memiliki tugas untuk mewujudkan tujuan negara dimana lembaga tersebut diberikan kewenangan untuk melaksanakan kepemimpinan dan koordinasi pemerintah baik pusat maupun daerah serta pembagunan masyarakat dari berbagai lembaga dimana mereka ditempatkan.

Dalam UU Nomor 32 tahun 2004 menjelaskan bahwa Pemerintah Daerah merupakan organisasi pemerintah yang menyelenggarakan urusan pemerintah di daerah menurut asas otonomi seluas-luasnya dan asas perbantuan dalam sistem NKRI. Tuntutan masyarakat terhadap tata kelola pemerintahan yang baik semakin meningkat, hal ini mendorong pemerintah baik pemerintah pusat maupun pemerintah daerah untuk menerapkan asas akuntabilitas publik, pengelolaan keuangan tersebut dilakukan secara tertib, transparan, dan akuntabel untuk mewujudkan pemerintah daerah yang baik.

Laporan Keuangan Pemerintah Daerah (LKPD) ialah bentuk laporan pertanggungjawaban atas pengelolaan keuangan daerah selama satu tahun anggaran. Baridwan (2000;17) mendifinisikan Laporan Keuangan daerah merupakan ringkasan dari suatu proses pencatatan, suatu ringkasan dari transaksi keuangan yang terjadi selama satu tahun buku yang bersangkutan. Kualitas laporan keuangan merupakan tolok ukur baik atau tidaknya atas pengelolaan keuangan pada pemerintah daerah. 
Laporan keuangan pemerintah daerah yang memiliki kualitas baik dapat dilihat dari opini Badan Pemeriksa Keuangan (BPK) selaku badan yang memeriksa dan menilai LKPD.

Anggriawan dan Yudianto (2014) berpendapat bahwa manajemen keuangan yang baik dalam organisasi pemerintah harus memiliki sumber daya manusia atau aparatur daerah yang berkualitas dengan latar belakang pendidikan dalam bidang akuntansi dan yang berpengalaman dalam bidang keuangan.

Selain kualitas aparatur pemerintah daerah, dalam penyusunan laporan keuangan juga dipengaruhi oleh Pemanfaatan Teknologi Informasi (PTI) juga merupakan salah satu faktor yang mempengaruhi kualitas laporan keuangan. Kewajiban Pemanfaatan Teknologi Informasi oleh pemerintah diatur dalam Peraturan Pemerintah Nomor 56 Tahun 2005 tentang Sistem Informasi Keuangan Daerah. Pemanfaatan Teknologi Informasi juga sangat membantu mempercepat proses pengelohan data transaksi dan penyajian laporan keuangan pemerintah, sehingga laporan keuangan tersebut tidak kehilangan nilai informasi yaitu ketepatwaktuan (Winidyaningrum, 2010).

Penerapan Sistem Akuntansi Keuangan Daerah juga merupakan salah satu faktor yang mempengaruhi kualitas laporan keuangan. Penerapan sistem akuntansi keuangan daerah merupakan pelaksanaan dalam menerapkan seluruh komponen dalam sistem akuntansi keuangan daerah yang berpedoman pada Peraturan Menteri Dalam Negeri No. 59 tahun 2007 tentang Pedoman Pengelolaan Keuangan Daerah.

\section{TINJAUAN LITERATUR}

\section{Kualitas Aparatur Daerah}

Kualitas aparatur daerah adalah kemampun seseorang atau individu dalam suatu organisasi atau suatu sistem untuk melaksanakan fungsi-fungsi untuk mencapai tujuannya secara efektif dan efisien. Menurut Bastian (2006: 55) bahwa penyiapan dan penyusunan laporan keuangan yang berkualitas memerlukan kualitas aparatur daerah yang menguasai akuntansi pemerintah. Triwardana (2017) menjelaskan pada hakikatnya, aparatur daerah berupa manusia yang dipekerjakan di sebuah organisasi sebagai penggerak, pemikir dan perencana untuk mencapai tujuan organisasi itu. Sumber daya manusia menjadi faktor penentu yang dapat menentukan keberhasilan pelaksanaa organisasi yang efektif (Griffin dan Ebert, 2010: 321).

Dalam Keputusan Kepala BKN No. 46A Tahun 2007 indikator kompetensi sumber daya manusia (pegawai) adalah: pengetahuan, keterampilan, dan sikap. Dalam pengelolaan keuangan daerah yang baik, SKPD harus memiliki aparatur daerah yang berkualitas yang didukung dengan latar belakang pendidikan akuntansi dan mempunyai pengalaman dibidang keuangan yang diperlukan untuk menerapkan sistem akuntansi yang ada. aparatur yang berkompeten akan mampu memahami logika akuntansi dengan baik.

\section{Sistem Akuntansi Keuangan Daerah}

Menurut Nordiawan (2008: 201) dan Permendagri No. 13 Tahun 2006 Tentang Pedoman Pengelolaan Keuangan Daerah mengatakan bahwa Sistem akuntansi pemerintah daerah adalah serangkaian prosedur mulai dari proses pengumpulan 
data, pencatatan, pengikhtisaran, sampai dengan pelaporan keuangan, dalam rangka pertanggungjawaban pelaksanaan anggaran pendapatan belanja daerah (APBD) yang dapat dilakukan secara manual atau menggunakan aplikasi komputer.

Sementara menurut Halim (2007: 43) Sistem akuntansi keuangan daerah adalah suatu proses identifikasi,pengukuran, dan pelaporan transaksi ekonomi (keuangan) dari suatu daerah (provinsi, kabupaten, kota) yang dijadikan sebagai informasi dalam pengambilan keputusan ekonomi oleh pihak-pihak yang memerlukan. Penelitian yang dilakukan oleh Rahayu dkk. (2014) menyatakan bahwa penerapan sistem akuntansi keuangan daerah berpengaruh signifikan terhadap kualitas laporan.

\section{Pemanfaatan Teknologi Informasi}

Suyanto (2005: 10) mengartikan bahwa teknologi informasi adalah sebuah bentuk umum yang menggambarkan setiap teknologi yang membantu menghasilkan, memanipulasi, menyimpan, mengkomunikasikan, dan atau menyampaikan informasi. Kamus Besar Bahasa Indonesia (KBBI) menjelaskan pemanfaatan adalah proses atau cara atau perbuatan memanfaatkan. Dengan demikian dapat disimpulkan bahwa pemanfaatan teknologi informasi adalah cara memanfaatkan suatu teknologi guna membantu memproses informasi, menyimpan, mengkomunikasikan dan menyampaikan informasi.

Winidyaningrum (2010) mengelompokkan Pemanfaatan Teknologi Informasi mencakup adanya: 1) Pengolahan data, pengolahan informasi, sistem manajemen dan proses kerja secara elektronik. 2)Pemanfaatan kemajuan teknologi informasi agar pelayanan publik dapat diakses dengan mudah oleh seluruh masyarakat.

Dalam penjelasan Peraturan Pemerintah No. 56 Tahun 2005 tentang Sistem Informasi Keuangan disebutkan bahwa untuk menindak lanjuti terselenggaranya proses pembangunan yang sejalan dengan prinsip tata kelola pemerintah baik pemerintah pusat dan pemerintah daerah berkewajiban untuk mengembangkan dan memanfaatkan kemajuan teknologi informasi untuk meningkatkan kemampuan mengelola keuangan, dan menyalurkan informasi keuangan kepada pelayanan publik.

Menurut Suyanto (2005: 11) Pemanfaatan Teknologi Informasi dapat diukur melalui penggunaan komponen perangkat keras komputer (Hardware), perangkat lunak komputer (Software), jaringan dan komunikasi.

\section{Kualitas Laporan Keuangan Pemerintah Daerah}

Kualitas menurut Mulyana (2010: 96) adalah Kualitas diartikan sebagai kesesuaian dengan standar, diukur berbasis kadar ketidaksesuaian, serta dicapai melalui pemeriksaan. Menurut Baridwan (2000: 17) Laporan Keuangan Daerah yaitu laporan keuangan daerah merupakan ringkasan dari suatu proses pencatatan, suatu ringkasan dari transaksi keuangan yang terjadi selama satu tahun buku yang bersangkutan.

Pada pemerintah daerah laporan keuangan merupakan hal yang sangat penting karena memiliki tujuan untuk menyajikan informasi yang berkaitan dengan posisi keuangan, realisasi anggaran, dan kinerja keuangan yang berguna untuk 
pemerintah daerah dalam menyusun dan mengevaluasi kebijakan dalam mengelola sumber dana.

Karakteristik kualitatif laporan keuangan yang dijelaskan oleh Peraturan Pemerintah No. 71 Tahun 2010 tentang Standar Akuntansi Pemerintahan (SAP) adalah ukuran-ukuran normatif yang perlu diwujudkan dalam informasi akuntansi sehingga dapat memenuhi tujuannya. Keempat karakteristik berikut ini merupakan prasyarat normatif yang diperlukan agar laporan keuangan pemerintah daerah dapat memenuhi kualitas yang dikehendaki diantaranya: relevan (memiliki manfaat umpan balik, memiliki manfaat prediktif, tepat waktu, dan lengkap); andal (penyajian jujur, dapat diverifikasi, netralitas); dapat dibandingkan; dan dapat dipahami.

\section{METODE}

\section{Metode Penelitian}

Penelitian ini merupakan penelitian kuantitatif dengan paradigma penelitian positivistik. Penelitian ini bertujuan untuk mengetahui pengaruh Kualitas Aparatur Pemerintah, Sistem Akuntansi Keuangan Daerah, dan Pemanfaatan Teknologi Informasi terhadap Kualitas Laporan Keuangan Pemerintah Daerah.

Populasi dalam penelitian ini adalah pegawai yang berkerja di bagian Badan Keuangan Daerah (BKD) Kabupaten Sukoharjo. Penelitian ini menggunakan metode purposive sampling untuk menentukan jumlah sampel penelitian. Purposive sampling adalah teknik penentuan sampel dengan pertimbangan tertentu (Sugiyono, 2014: 96). Adapun responden dalam penelitian ini adalah pegawai BKD, jadi sampel dalam penelitian ini sebanyak 72. Alasan pemilihan sampel tersebut adalah bahwa pegawai tersebut merupakan pihak-pihak yang terlibat langsung dalam penyusunan laporan keuangan. Jenis data dalam penelitian ini adalah data primer. Data yang digunakan ini bersumber dari kuesioner. Sumber data dalam penelitian ini adalah jawaban dari kuesioner yang dibagikan kepada responden.

Dalam penelitian ini skala pengukuran yang digunakan adalah skala likert. Skala likert yang digunakan dalam penelitian ini berdimensi 4 yaitu Sangat Setuju (SS), Setuju (S), Tidak Setuju (TS) dan Sangat Tidak Setuju (STS). Penelitian ini meniadakan kategori jawaban ragu-ragu atau netral dengan berdasarkan tiga alasan (Hadi, 1991: 19), yaitu: kategori undecided mempunyai arti ganda, biasa diartikan belum dapat memutuskan atau memberikan jawaban, tersedianya jawaban netral menimbulkan kecenderungan jawaban responden ketengah, dan maksud kategori jawaban Sangat Setuju (SS), Setuju (S), Tidak Setuju (TS), dan Sangat Tidak Setuju (STS) untuk melihat kecenderungan responden kearah setuju atau tidak setuju.

Variabel dependen atau terikat adalah variabel yang dipengaruhi oleh variabel lainnya. Yaitu Kualitas Laporan Keuangan Pemerintah Daerah (Y). Variabel independen atau bebas adalah variabel yang mempengaruhi variabel lainnya, yaitu Kualitas Aparatur Pemerintah (X1), Sistem Akuntansi Keuangan Daerah (X2), dan Pemanfaatan Teknologi Informasi (X3).

Metode analisis data menggunakan statistik deskriptif, uji instrumen, dan uji hipotesis. Statistik deskripstif memberikan gambaran atau deskripsi suatu data yang dilihat dari nilai rata-rata (mean), standar deviasi, maksimum, minimum, sum. Untuk melakukan uji instrumen data atas data primer ini, maka peneliti melakukan uji reliabilitas dan validitas. Jika nilai croanbach alpha diatas 0,60 maka data dikatakan 
reliabel, sedangkan pengujian validitas dinilai dengan pearson correlation. Jika nilai signifikansi pearson corelation dibawah 0,05 maka data tersebut dinyatakan valid.

Uji hipotesis yang akan dilakukan dalam penelitian ini adalah Koefisien Determinasi, Uji Statistik t dan Uji Statistik F. Pengujian hipotesis dilakukan untuk melihat seberapa besar variabel independen tersebut mempengaruhi variabel dependen. Jika nilai signifikansi pada pengujian statistik $\mathrm{t}$ dan statistik $\mathrm{f}$ dibawah 0,05 maka hipotesis diterima dan sebaliknya.

\section{Model Persamaan}

Penelitian ini menggunakan model linier berganda. Alat analisis dalam penelitian ini menggunakan perangkat lunak SPSS. Hasan (2008) menyatakan Analisis regresi berganda digunakan untuk mengetahui pengaruh variabel bebas terhadap variabel terikatnya secara bersama-sama dan secara parsial.Dalam penelitian ini persamaan regresi bergandanya adalah:

$Y=a+b 1 X 1+b 2 X 2+b 3 X 3+e$

Dimana:

$\mathrm{Y} \quad=$ Variabel kualitas laporan keuangan pemerintah daerah

$\mathrm{X} 1=$ Variabel kualitas aparatur daerah

$\mathrm{X} 2=$ Variabel sistem akuntansi keuangan daerah

$\mathrm{X} 3=$ Variabel pemanfaatan teknologi informasi

a $\quad=$ Konstanta

$\mathrm{b} \quad=$ Koefisien regresi

e $\quad=$ Error term (kesalahan pengganggu)

\section{HASIL DAN PEMBAHASAN}

\section{Statistik Deskriptif}

Statistik untuk setiap variabel dependen dan independen yang dianalisis disajikan dalam tabel statistik deskriptif. Dari analisis statistik deskriptif akan dapat diperoleh nilai rata-rata (mean), minimum, standar deviasi, dan nilai maksimum skor total dari setiap variabel (Sugiyono, 2011: 32). Berdasarkan hasil dari pengolahan data maka statistik dekriptif dari variabel-variabel dapat dilihat pada tabel dibawah ini:

Tabel 1. Statistik Deskriptif

\begin{tabular}{cccccc}
\hline Variabel & $\mathrm{N}$ & Minimum & Maximum & Mean & Std. Deviation \\
\hline KAD & 72 & 14 & 26 & 21,39 & 2,032 \\
\hline SAKD & 72 & 21 & 30 & 24,36 & 1,638 \\
\hline PTI & 72 & 17 & 24 & 19,86 & 2,222 \\
\hline LKPD & 72 & 32 & 48 & 37,51 & 2,979
\end{tabular}

Sumber: Data diolah 
Dari Tabel 1 Kualitas Aparatur Daerah menunjukkan nilai minimum sebesar 14 dan nilai maksimum sebesar 26 dari 7 pertanyaan. Nilai mean sebasar 21,39 dan nilai standar devisi sebesar 2,032. Sistem Akuntansi Keuangan Daerah menunjukkan nilai minimum sebesar 21 dan nilai maksimum sebesar 30 dari 8 pertanyaan. Nilai mean sebasar 24,36 dan nilai standar devisi sebesar 1,638. Pemanfaatan teknologi informasi menunjukkan nilai minimum sebesar 17 dan nilai maksimum sebesar 24 dari 6 pertanyaan. Nilai mean sebasar 19,86 dan nilai standar devisi sebesar 2,222.

\section{Hasil Uji Instrumen Uji Validitas}

Teknik yang digunakan untuk melakukan uji validitas tersebut adalah dengan menggunakan koefisien korelasi Pearson correlation dibantu dengan SPSS versi 21. Data dikatakan valid apabila korelasi antar skor masing-masing butir pernyataan dengan total skor setiap konstruknya signifikan pada level 0,05 maka pernyataan tersebut dikatakan valid. Selain itu juga dapat dikatakan valid jika angka $r$ hitung lebih besar dari $r$ tabel. Tabel 2.

Hasil uji validitas variabel Kualitas Aparatur Daerah (X1) dapat dilihat dalam

Tabel 2. Hasil Uji Validitas Kualitas Aparatur Daerah (X1)

\begin{tabular}{cccc}
\hline $\begin{array}{c}\text { Butir } \\
\text { Pertanyaan }\end{array}$ & $\mathrm{r}_{\mathrm{xy}}$ & $\mathrm{r}_{\text {tabel }}$ & Keterangan \\
\hline 1 & 0,547 & 0,2319 & Valid \\
\hline 2 & 0,808 & 0,2319 & Valid \\
\hline 3 & 0,822 & 0,2319 & Valid \\
\hline 4 & 0,581 & 0,2319 & Valid \\
\hline 5 & 0,576 & 0,2319 & Valid \\
\hline 6 & 0,545 & 0,2319 & Valid \\
\hline 7 & 0,573 & 0,2319 & Valid \\
\hline
\end{tabular}

\section{Sumber: Data diolah}

Nilai $r_{\text {tabel }}$ untuk sampel sebesar 72 dengan taraf signifikansi 0,05 adalah sebesar 0,2319. Dari tabel 2 dapat dijelaskan bahwa semua pertanyaan tentang variabel kompetensi sumber daya manusia $\left(X_{1}\right)$ menunjukkan keterangan valid. Hal ini dikarenakan nilai $r_{\text {hitung }}(0,545-0,822)>r_{\text {tabel }}(0,2319)$.

Hasil uji validitas variabel Sistem Akuntansi Keuangan Daerah (X2) dapat dilihat dalam Tabel 3. 
Tabel 3. Hasil Uji Validitas SAKD (X2)

\begin{tabular}{cccc}
\hline $\begin{array}{c}\text { Butir } \\
\text { Pertanyaan }\end{array}$ & $\mathrm{r}_{\mathrm{xy}}$ & $\mathrm{r}_{\text {tabel }}$ & Keterangan \\
\hline 1 & 0,521 & 0,2319 & Valid \\
\hline 2 & 0,479 & 0,2319 & Valid \\
\hline 3 & 0,613 & 0,2319 & Valid \\
\hline 4 & 0,458 & 0,2319 & Valid \\
\hline 5 & 0,453 & 0,2319 & Valid \\
\hline 6 & 0,656 & 0,2319 & Valid \\
\hline 7 & 0,656 & 0,2319 & Valid \\
\hline 8 & 0,637 & 0,2319 & Valid \\
\hline
\end{tabular}

Sumber: Data diolah

Nilai $r_{\text {tabel }}$ untuk sampel sebesar 72 dengan taraf signifikansi 0,05 adalah sebesar 0,2319. Dari tabel 3 dapat dijelaskan bahwa semua pertanyaan tentang variabel penerapan sistem akuntansi keuangan Daerah (X3) menunjukkan keterangan valid. Hal ini dikarenakan nilai $r_{\text {hitung }}(0,453-0,656)>r_{\text {tabel }}(0,2319)$.

Hasil uji validitas variabel Pemanfaatan Teknologi Informasi $\left(X_{3}\right)$ dapat dilihat dalam Tabel 4.

Tabel 4. Hasil Uji Validitas Pemanfaatan Teknologi Informasi (X3)

\begin{tabular}{cccc}
\hline $\begin{array}{c}\text { Butir } \\
\text { Pertanyaan }\end{array}$ & $\mathrm{r}_{\mathrm{xy}}$ & $\mathrm{r}_{\text {tabel }}$ & Keterangan \\
\hline 1 & 0,723 & 0,2319 & Valid \\
\hline 2 & 0,792 & 0,2319 & Valid \\
\hline 3 & 0,809 & 0,2319 & Valid \\
\hline 4 & 0,733 & 0,2319 & Valid \\
\hline 5 & 0,839 & 0,2319 & Valid \\
\hline 6 & 0,812 & 0,2319 & Valid \\
\hline
\end{tabular}

Sumber: Data diolah

Nilai $r_{\text {tabel }}$ untuk sampel sebesar 72 dengan taraf signifikansi 0,05 adalah sebesar 0,2319. Dari tabel 3 dapat dijelaskan bahwa semua pertanyaan tentang variabel pemanfaatan teknologi informasi $\left(X_{3}\right)$ menunjukkan keterangan valid. Hal ini dikarenakan nilai $r_{\text {hitung }}(0,723-0,839)>r_{\text {tabel }}(0,2319)$.

Hasil uji validitas variabel kualitas LKPD (Y) dapat dilihat dalam Tabel 5. Nilai $r_{\text {tabel }}$ untuk sampel sebesar 72 dengan taraf signifikansi 0,05 adalah sebesar 0,2319. Dari tabel 5 dapat dijelaskan bahwa semua pertanyaan tentang variabel kualitas laporan keuagan pemerintah daerah $(\mathrm{Y})$ menunjukkan keterangan valid. Hal ini dikarenakan nilai $r_{\text {hitung }}(0,585-0,755)>r_{\text {tabel }}(0,2319)$. 
Tabel 5. Hasil Uji Validitas Kualitas LKPD (Y)

\begin{tabular}{cccc}
\hline $\begin{array}{c}\text { Butir } \\
\text { Pertanyaan }\end{array}$ & $\mathrm{r}_{\mathrm{xy}}$ & $\mathrm{r}_{\text {tabel }}$ & Keterangan \\
\hline 1 & 0,677 & 0,2319 & Valid \\
\hline 2 & 0,755 & 0,2319 & Valid \\
\hline 3 & 0,646 & 0,2319 & Valid \\
\hline 4 & 0,724 & 0,2319 & Valid \\
\hline 5 & 0,680 & 0,2319 & Valid \\
\hline 6 & 0,585 & 0,2319 & Valid \\
\hline 7 & 0,688 & 0,2319 & Valid \\
\hline 8 & 0,687 & 0,2319 & Valid \\
\hline 9 & 0,640 & 0,2319 & Valid \\
\hline 10 & 0,701 & 0,2319 & Valid \\
\hline 11 & 0,722 & 0,2319 & Valid \\
\hline 12 & 0,644 & 0,2319 & Valid
\end{tabular}

Sumber: Data diolah, 2019

\section{Uji Reliabilitas}

Uji Reliabilitas dilakukan dengan menghitung cronbach's alpha dari masingmasing instrument dengan menggunakan program SPSS versi 21 . Untuk melihat andal atau tidaknya suatu ukur yang digunakan pendekatan secara statistika yaitu melalui koefisien reliabilitas dan apabila koefisien reliabilitasnya lebih besar dari 0.60 maka secara keseluruhan pernyataan tersebut dinyatakan andal (reliabel).

Tabel 6. Hasil Uji Reliabilitas Instrumen Penelitian

\begin{tabular}{lccc}
\hline \multicolumn{1}{c}{ Variabel } & $\begin{array}{c}\text { Cronbach's } \\
\text { Alpha }\end{array}$ & Nilai Kritis & Keterangan \\
\hline Kualitas Aparatur Daerah $(\mathrm{X} 1)$ & 0,761 & 0,60 & Reliabel \\
\hline Pemanfaatan TI (X2) & 0,654 & 0,60 & Reliabel \\
\hline Penerapan SAKD (X3) & 0,874 & 0,60 & Reliabel \\
\hline Kualitas LKPD (Y) & 0,890 & 0,60 & Reliabel \\
\hline
\end{tabular}

Sumber: Data diolah, 2019

Dari tabel diatas dapat dijelaskan bahwa hasil uji reliabilitas instrumen diperoleh nilai Cronbach's Alpha masing-masing variabel $\geq 0,60$. Dengan demikian seluruh variabel dapat dinyatakan reliabel.

\section{Hasil Uji Hipotesis}

\section{Analisis Regresi Linier Berganda}

Hasil uji t disajikan dalam Tabel 7. 
Tabel 7. Analisis Regresi Linier Berganda

\begin{tabular}{lll}
\hline Variabel Independen & B & Standard Eror \\
\hline Konstanta & 19,600 & 5,644 \\
\hline Kualitas Aparatur Daerah $(\mathrm{X} 1)$ & $-0,140$ & 0,170 \\
\hline SAKD $(\mathrm{X} 2)$ & 0,426 & 0,205 \\
\hline Pemanfaatan TI (X3) & 0,530 & 0,149
\end{tabular}

Sumber: Data diolah, 2019

Dari tabel diatas dapat disusun persamaan regresi sebagai berikut:

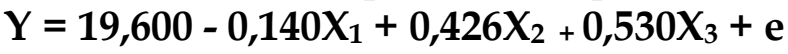

Dari persamaan regresi tersebut, terdapat interpretasi yang dapat dijelaskan sebagai berikut:

1. Nilai konstanta sebesar 19,600 hal ini menunjukkan bahwa variabel independen $\left(X_{1}, X_{2}\right.$, dan $\left.X_{3}\right)$ berupa kualitas aparatur daerah, sistem akuntansi keuangan daerah,dan pemanfaatan teknologi informasi mampu memberikan konstribusi yang besar dalam mempengaruhi kualiatas laporan keuangan daerah (Y) sebesar 19,600.

2. Nilai variabel kualitas aparatur daerah sebesar $-0,140$ artinya jika variabel independen lain nilainya tetap dan kualitas aparatur daerah mengalami kenaikan 1\%, maka kualitas laporan keuangan mengalami penurunan sebesar 0,140 .

3. Nilai variabel sistem akuntansi keuangan daerah sebesar 0,426 artinya jika variabel independen lain nilainya tetap dan penerapan standar akuntansi pemerintah mengalami kenaikan 1\%, maka kualitas pelaporan keuangan mengalami peningkatan sebesar 0,426 .

4. Nilai variabel pemanfaatan teknologi informasi sebesar 0,530 artinya jika variabel independen lain nilainya tetap dan pemanfaatan teknologi informasi mengalami kenaikan 1\%, maka kualitas pelaporan keuangan mengalami peningkatan sebesar 0,530 .

\section{Uji Signifikansi (Uji t)}

Uji signifikan parameter individual (uji statistik t) digunakan untuk mengetahui seberapa besar pengaruh satu variabel independen terhadap variabel dependen. Jika nilai signifikansi $\mathrm{t}$ dari variabel pengujian lebih kecil dari nilai signifikansi 0,05 maka secara parsial variabel indipenden berpengaruh terhadap variabel dependen, begitu juga sebaliknya (Ghozali, 2011: 98-99). Jika nilai t hitung > $\mathrm{t}$ tabel maka secara parsial variabel independen berpengaruh terhadap variabel dependen, begitu juga sebaliknya. 
Tabel 8. Hasil Uji t

\begin{tabular}{lcccc}
\hline \multicolumn{1}{c}{ Variabel } & $\boldsymbol{t}_{\text {hitung }}$ & $\mathbf{t}_{\text {tabel }}$ & $\boldsymbol{P}_{\text {value }}$ & Simpulan \\
\hline Kualitas Aparatur Daerah (X1) & $-0,824$ & 1,995 & 0,413 & Tidak Signifikan \\
\hline SAKD (X2) & 2,076 & 1,995 & 0,042 & Signifikan \\
\hline Pemanfaatan TI (X3) & 3,555 & 1,995 & 0,001 & Signifikan \\
\hline
\end{tabular}

Sumber: Data diolah, 2019

Dari Tabel 8 dapat dijelaskan bahwa variabel KAD secara parsial tidak berpengaruh signifikan terhadap kualitas laporan keuangan pemerintah daerah, hal ini dapat dilihat dari nilai $t_{\text {hitung }}$ sebesar $-0,824$ lebih kecil dari $t_{\text {tabel }}$ sebesar 1,668 dengan nilai signifikansi $0,413>0,05$ yang artinya bahwa variabel SKAD secara parsial tidak berpengaruh signifikan terhadap kualitas laporan keuangan pemerintah daerah Kabupaten Sukoharjo. Maka hipotesis pertama $\left(\mathrm{H}_{1}\right)$ ditolak.

\section{Uji Koefisien Determinasi $\left(R^{2}\right)$}

Hasil perhitungan Adjusted $R^{2}$ dapat diketahui persentase yang dapat dijelaskan oleh variabel independen terhadap variabel dependen. Berikut hasil uji $\mathrm{R}^{2}$ dapat dilihat pada Tabel 9.

Tabel 9. Hasil Uji Koefisien Determinasi

\begin{tabular}{llll}
\hline $\mathrm{R}$ & R Square & Adjusted R Square & Std. Error of the Estimate \\
\hline 0,720 & 0,519 & 0,471 & 1,956
\end{tabular}

Sumber: Data diolah, 2019

Berdasarkan hasil analisis dari Tabel 9 bahwa nilai Adjusted $R^{2}$ sebesar 0,471, ini menunjukkan bahwa ketiga variabel yang menjadi tolok ukur kualitas pelaporan keuangan pemerintah daerah mampu menjelaskan terhadap variasi perubahan variasi kualitas pelaporan keuangan pemerintah daerah sebesar 47,1\% sedangkan sisanya sebesar 52,9\% dijelaskan oleh variabel lain yang tidak digunakan dalam penelitian ini.

\section{Pembahasan}

Dalam pencapaian suatu efektivitas pengelolaan keuangan yang berkualitas tentu memerlukan sumber daya manusia yang berkualitas. Menurut Bastian (2006:55) bahwa penyiapan dan penyusunan laporan keuangan yang berkualitas memerlukan SDM yang menguasai akuntansi pemerintah. Hasil penelitian ini sejalan dengan hasil penelitian sebelumnya oleh Aritonang (2018) dimana hasil penelitaan yang dilakukan menujukkan bahwa kompetensi sumber daya manusia tidak berpengaruh signifikan terhadap kualitas laporan keuangan. Tetapi tidak sejalan dengan penelitian yang dilakukan Synthia (2017), Triwardana (2017), dan Aini (2015) bahwa kompetensi sumber daya manusia/kualitas aparatur daerah berpengaruh signifikan terhadap kualitas laporan keuangan pemerintah daerah. 
Variabel penerapan SAKD secara parsial berpengaruh signifikan terhadap kualitas laporan keuangan pemerintah daerah, hal ini dapat dilihat dari nilai thitung sebesar 2,076 lebih besar dari ttabel sebesar 1,668 dengan nilai signifikansi 0,042<0,05 yang artinya bahwa variabel SAKD secara parsial berpengaruh signifikan terhadap kualitas laporan keuangan pemerintah daerah Kabupaten Sukoharjo. Maka hipotesis kedua (H2) diterima.

Hal ini menunjukkan bahwa penerapan sistem akuntansi keuangan daerah memiliki peran penting dalam meningkatkan kualitas laporan keuangan Pemda Kabupaten Sukoharjo. Penerapan sistem akuntansi keuangan daerah memiliki tujuan agar pelaksanaan pemerintah berjalan terstruktur dan sesuai pedoman sehingga akan menghasilkan laporan keuangan yang berkualitas. Jadi Pemda Kabupaten Sukoharjo harus dapat menerapkan sistem akuntansi keuangan daerah agar kualitas laporan keuangan berkualitas dan tepat waktu.

Hasil Penelitian ini sejalan yang dilakukan oleh Rahayu dkk. (2014), Wardani dan Nugroho (2018) yang menunjukkan bahwa kompetensi sumber daya manusia, penerapan sistem akuntansi keuangan daerah dan penerapan standar akuntansi pemerintah berpengaruh signifikan terhadap kualitas laporan

Variabel pemanfaatan teknologi informasi secara pasial berpengaruh signifikan terhadap kualitas laporan keuangan pemerintah daerah, hal ini dapat dilihat dari nilai thitung sebesar 3,555 lebih besar dari ttabel sebesar 1,668 dengan nilai signifikansi 0,001<0,05 yang artinya bahwa variabel pemanfaatan teknologi informasi secara parsial berpengaruh signifikan terhadap kualitas pelaporan keuangan pemerintah daerah. Maka hipotesis ketiga (H3) diterima.

Lestari dan Zulaikha (2007: 15) menjelaskan bahwa penggunaan teknologi informasi diharapkan dapat meningkatkan kualitas informasi dalam menyusun laporan keuangan terutama berkaitan dengan keandalan dan ketepatan waktu aspek penyampaian pelaporan keuangan. Selain itu dengan adanya teknologi informasi dapat membuat pekerjaan pegawai lebih akurat dan cepat. Hasil peneletian ini sejalan dengan penelitian yang dilakukan oleh peneliti terdahulu yaitu Aini (2015) dan Aritonang (2018) yang hasil penelitiaannya menunjukkan hasil pemanfaatan teknologi informasi berpengaruh signifikan terhadap kualitas laporan keuangan pemerintah daerah.

\section{SIMPULAN}

Berdasarkan hasil pembahasan yang telah dijelaskan di atas maka dapat disimpulkan bahwa kualitas aparatur daerah secara parsial tidak berpengaruh signifikan terhadap kualitas laporan keuangan pemerintah daerah Kabupaten Sukoharjo, sistem akuntansi keuangan daerah secara parsial berpengaruh signifikan terhadap kualitas laporan keuangan pemerintah daerah Kabupaten Sukoharjo, pemanfaatan teknologi informasi secara parsial berpengaruh signifikan terhadap kualitas pelaporan keuangan pemerintah daerah Kabupaten Sukoharjo.

Rekomendasi yang dapat diberikan oleh penulis yaitu: bagi Pemerintah Daerah Kabupaten Sukoharjo agar lebih memperhatikan kompetensi sumber daya manusia para pegawai pemerintah. Pemanfaatan teknologi informasi dan penerapan standar akuntansi pemerintah di tingkat SKPD perlu menjadi bahan perhatian, karena sangat membantu para pegawai dalam melaksanakan tugasnya dengan baik. 
Kemudian bagi penelitian selanjutnya, diharapkan untuk penelitian mendatang sebaiknya menambah variabel independen lainnya guna mengetahui variabelvariabel lain yang dapat mempengaruhi kualitas pelaporan keuangan pemerintah daerah.

\section{DAFTAR PUSTAKA}

Aini, Fitratul. (2015). Pengaruh Pengendalian Intern, Pemanfaatan Teknologi Informasi, dan Kualitas Sumber Daya Manusia Terhadap Keterandalan Pelaporan Keuangan Daerah (Studi Pada Satuan Kerja Perangkat Daerah Kota Payakumbuh). Jurnal Online Mahasiswa Fakultas Ekonomi Vol. 2 No. 2 (2015) h. 18. https://jom.unri.ac.id/index.php/JOMFEKON/article/view/ 8895

Anggriawan, Fakhri T. dan Yudianto, Ivan. (2018). Factors Affecting Information Quality of Local Government Financial Statement. Journal of Accounting Auditing $\begin{array}{lllllll}\text { and Business } & \text { Vol. } & 1 & \text { No. } & 1 & \text { (2018) } & \text { h. }\end{array}$ http://jurnal.unpad.ac.id/jaab/article/view/15652/7353

Aritonang, Jeremia S. P. (2018). Pengaruh Kompetensi Sumber Daya Manusia, Penerapan Standar Sistem Pengendalian Internal, Penerapan Standar Akuntansi Pemerintahan dan Pemanfaatan Teknologi Informasi Terhadap Kualitas Laporan Keuangan Pemerintah Daerah (Studi Kasus pasa SKPD Kabupaten Dairi. Skripsi. Fakultas Ekonomi dan Bisnis Universitas Sumatera Utara.

Baridwan, Zaki. (2000). Sistem Akuntansi Penyusunan Prosedur dan Metode Edisi Ke Tujuh. Yogyakarta: BPFE.

Bastian, I. (2006). Akuntansi Sektor Publik: Suatu Pengantar. Jakarta: Erlangga.

Ghozali, Imam. (2011). Aplikasi Analisis Multivariate Dengan Program IBM SPSS 19 Edisi 5. Semarang: Penerbit Universitas Diponegoro.

Ghozali, Imam. (2013). Aplikasi Analisis Multivariate Dengan Program IBM SPSS 21 Update PLS Regresi. Semarang: Penerbit Universitas Diponegoro.

Griffin, Ebert. (2010). Bisnis (edisi jilid I). Jakarta: Indeks.

Hadi, Sutrisno. (1991). Analisis Butir untuk Instrumen Angket, Tes, dan Skala Nilai. Yogyakarta: FP UGM.

Halim, Abdul. (2007). Akuntansi Keuangan Daerah. Yogyakarta: Salemba Empat.

Hasan, M. Iqbal. (2008). Pokok-Pokok Materi Statistik 1 ( Statistik Deskriptif) Edisi Kedua. Jakarta: Bumi Aksara. 
KBBI, (2019). Kamus Besar Bahasa Indonesia (KBBI). [online] Available at http:/kbbi.web.id/rehabilitasi, [Diakses pada 10 Maret 2019]

Keputusan Kepala Badan Kepegawaian Negara No 46A Tahun 2007. Pedoman Penyusunan Standar Kompetensi Jabatan Struktural Pegawai Negeri Sipil. http:/ / mahsanafifiles.wordpress.com (Diakses pada 1 November 2015)

Lasoma, A.V. (2012). "Pengaruh Standar Akuntansi Pemerintah Terhadap Kualitas Laporan Keuangan Pemerintah Daerah pada Dinas Pendapatan dan Pengelolaan Keuangan dan Aset Daerah Kabupaten Gorontalo Utara." Jurnal Akuntansi Vol. 2 No. 1.

Lestari, Anggun dan Zulaikha. (2007). Influence of Information Technology Relatedness to Company Performance with Knowledge Management Capability as Intervening variable (Empirical Study on Banking Company in Central Java). Proceeding. Symposium on Accounting X Makassar.

Mulyana, Iman. (2010). Manajemen dan Kehidupan Manusia. Yogyakarta: Kanisius.

Peraturan Pemerintah No. 56 Tahun 2005 tentang Sistem Informasi Keuangan Daerah.

Permendagri No. 13 Tahun 2006 dan Permendagri No.59 Tahun 2007 tentang Pedoman Pengelolaan Keuangan daerah.

Rahayu, Liza, Kennedy, dan Anisma, Yuneita. (2014). Pengaruh Kompetensi Sumber Daya Manusia, Penerapan Sistem Akuntansi Keuangan Daerah dan Penerapan Standar Akuntansi Pemerintah terhadap Kualitas Laporan Keuangan Daerah pada Pemerintah Provinsi Riau (Studi Empiris pada SKPD Provinsi Riau). Jurnal Online Mahasiswa Fakultas Ekonomi Vol. 1 No. 2 (2014). https://jom.unri.ac.id/index.php/JOMFEKON/article/view/4464/4348

Sugiyono. (2011). Metode Penelitian Kuantitatif, Kualitatif dan RED. Bandung: CV. Alfabeta.

Sugiyono. (2014). Metode Penelitian Kuantitatif, Kualitatif dan RED. Bandung: CV. Alfabeta.

Suyanto. (2005). Pengantar Teknologi Informasi Untuk Bisnis. Yogyakarta: Andi.

Synthia. (2017). The Effect of Human Resources Competence and Application of Regional Financial Accounting Systems on Quality of Financial Report. Journal of Applied Accounting and Taxation Vol. 2 No. 1 March 2017 p. 68-74. https://jurnal.polibatam.ac.id/index.php/JAAT/article/view/551/377

Triwardana, Dhedy. (2017). Pengaruh penerapan standar akuntansi pemerintah, penerapan akuntansi keuangan daerah, dan kompetensi sumber daya manusia 
dan penerapan sistem akuntansi keuangan daerah terhadap kualitas laporan keuangan SKPD (Studi Pada Pemerintah Daerah Kabupaten Kampar). Jurnal Online Mahasiswa Fakultas Ekonomi Vol. 4 No. 1 Februari 2017 h. 641-655. https://jom.unri.ac.id/index.php/JOMFEKON/article/view/12387/12032

Undang-Undang Republik Indonesia Nomor 17 Tahun 2003 tentang Keuangan Negara.

Undang-Undang Republik Indonesia Nomor 32 Tahun 2004 tentang Pemerintah Pusat dan Pemerintah Daerah.

Wardani, Dewi K., dan Nugroho, Simon P. (2018). The Impact of Information Technology on Financial Statement Quality: A Moderating Role of Internal Control System. Proceeding. The 1st International Conference on Advance \& Scientific Innovation, $4^{\text {th }}$ Jul 2018.

Winidyaningrum, C. (2010). Pengaruh SDM dan Pemanfaatan TI Terhadap Keterandalan dan Ketepatwaktuan Pelaporan Keuangan Pemerintah Daerah Dengan Variabel Intervening Pengendalian Intern Akuntansi. Jurnal Simposium Nasional Akuntansi (SNA). STIE STP Pignatelli Surakarta. 
Yuwita Ariessa Pravasanti E Suhesti Ningsih

Halaman ini sengaja dikosongkan 